\title{
Community shifts and carbon translocation within metabolically-active rhizosphere microorganisms in grasslands under elevated $\mathrm{CO}_{2}$
}

\author{
K. Denef ${ }^{1}$, H. Bubenheim ${ }^{2}$, K. Lenhart ${ }^{2}$, J. Vermeulen $^{1}$, O. Van Cleemput ${ }^{1}$, P. Boeckx ${ }^{1}$, and C. Müller ${ }^{2,3}$ \\ ${ }^{1}$ Laboratory of Applied Physical Chemistry, Ghent University, Coupure Links 653, 9000 Gent, Belgium \\ ${ }^{2}$ Justus-Liebig-University Gießen, Heinrich-Buff-Ring 26-32, 35392 Gießen, Germany \\ ${ }^{3}$ School of Biology and Environmental Science, University College Dublin Belfield, Dublin 4, Ireland
}

Received: 17 April 2007 - Published in Biogeosciences Discuss.: 8 May 2007

Revised: 14 September 2007 - Accepted: 17 September 2007 - Published: 24 September 2007

\begin{abstract}
The aim of this study was to identify the microbial communities that are actively involved in the assimilation of rhizosphere- $\mathrm{C}$ and are most sensitive in their activity to elevated atmospheric $\mathrm{CO}_{2}$ in a temperate semi-natural low-input grassland ecosystem. For this, we analyzed ${ }^{13} \mathrm{C}$ signatures in microbial biomarker phospholipid fatty acids (PLFA) from an in-situ ${ }^{13} \mathrm{CO}_{2}$ pulse-labeling experiment in the Giessen Free Air Carbon dioxide Enrichment grasslands (GiFACE, Germany) exposed to ambient and elevated (i.e. $50 \%$ above ambient) $\mathrm{CO}_{2}$ concentrations. Short-term ${ }^{13} \mathrm{C}$ PLFA measurements at $3 \mathrm{~h}$ and $10 \mathrm{~h}$ after the pulselabeling revealed very little to no ${ }^{13} \mathrm{C}$ enrichment after $3 \mathrm{~h}$ in biomarker PLFAs and a much greater incorporation of new plant-C into fungal compared to bacterial PLFAs after $10 \mathrm{~h}$. After a period of 11 months following the pulselabeling experiment, the ${ }^{13} \mathrm{C}$ enrichment of fungal PLFAs was still largely present but had decreased, while bacterial PLFAs were much more enriched in ${ }^{13} \mathrm{C}$ compared to a few hours after the pulse-labeling. These results imply that new rhizodeposit- $\mathrm{C}$ is rapidly processed by fungal communities and only much later by the bacterial communities, which we attributed to either a fungal-mediated translocation of rhizosphere- $\mathrm{C}$ from the fungal to bacterial biomass or a preferential bacterial use of dead root or fungal necromass materials as $\mathrm{C}$ source over the direct utilization of fresh rootexudate $\mathrm{C}$ in these $\mathrm{N}$-limited grassland ecosystems. Elevated $\mathrm{CO}_{2}$ caused an increase in the proportional ${ }^{13} \mathrm{C}$ enrichment (relative to the universal biomarker 16:0) of the arbuscular mycorrhizal fungal biomarker PLFA 16:1 $\omega 5$ and one grampositive bacterial biomarker PLFA i16:0, but a decrease in the proportional ${ }^{13} \mathrm{C}$ enrichment of $18: 1 \omega 9 \mathrm{c}$, a commonly used though questionable fungal biomarker PLFA. This sug-
\end{abstract}

Correspondence to: K. Denef

(karolien.denef@ugent.be) gests enhanced fungal rhizodeposit- $\mathrm{C}$ assimilation only by arbuscular mycorrhizal fungal species under elevated $\mathrm{CO}_{2}$.

\section{Introduction}

In the last 150 years, the atmospheric $\mathrm{CO}_{2}$ concentration has increased by approximately $33 \%$ due to human activity, and is predicted to continue to rise by $0.4 \%$ per year (Alley et al., 2007). A continued rise in $\mathrm{CO}_{2}$ may stimulate plant biomass production as well as root growth when sufficient mineral nutrients are available (Curtis and Wang, 1998; Ghannoum et al., 2000). This could result in greater carbon inputs into the soil due to higher rates of plant litterfall, root turnover and rhizodeposition (Rogers et al., 1994; Cotrufo and Gorissen, 1997; Sadowsky and Schortemeyer, 1997; DeLucia et al., 1999) as well as alterations in the chemical composition of plant tissues (e.g. higher $\mathrm{C} / \mathrm{N}$ ratio) and root exudates (Cotrufo et al., 1994; Jongen et al., 1995; Schortemeyer et al., 1996). Soil microorganisms are the key processors of soil organic matter and heavily rely on organic $\mathrm{C}$ supply for their growth. Any change in the amount and/or composition of plant material input into the soil in response to elevated $\mathrm{CO}_{2}$ is therefore likely to affect soil microbial growth and metabolism of plant-derived substrates, and consequently $\mathrm{C}$ and $\mathrm{N}$ cycling in soils (Zak et al., 1993). In $\mathrm{N}$ limited systems, an enhanced $\mathrm{C}$ input under increased $\mathrm{CO}_{2}$ could also alter microbial community composition in favor of fungi. Fungi are capable of colonizing nutrient-poor and recalcitrant substrates due to their greater and more variable $\mathrm{C}: \mathrm{N}$ ratio, their wide-ranging enzymatic capabilities and their ability to translocate essential nutrients through their hyphae over considerable distances (Frankland et al., 1990; Hu et al., 2001). Alterations in

Published by Copernicus Publications on behalf of the European Geosciences Union. 
soil microbial community composition could have significant consequences for $\mathrm{C}$ and $\mathrm{N}$ transformations. For instance, it has been postulated that bacteria-dominated food webs lead to greater short-term mineralization rates of organic $\mathrm{C}$ and $\mathrm{N}$ (Wardle et al., 2004), while fungal stimulation, in particular of arbuscular mycorrhizal fungi, may enhance $\mathrm{C}$ sequestration (Treseder and Allen, 2000; Bailey et al., 2002) and N immobilization through hyphal translocation (Beare, 1997; Frey et al., 2000).

Microbial community composition is frequently assessed through in-situ analyses of phospholipid fatty acids (PLFA), a diverse group of essential cell membrane lipids, several of which can be used as biomarkers for specific microbial groups (Vestal and White, 1989; Zelles, 1997). Phospholipids rapidly degrade following cell death and thus can be assumed to reflect the occurrence of living organisms. So far, contrasting results have been reported on the impacts of elevated $\mathrm{CO}_{2}$ on the composition of the microbial community based on PLFA profiles, ranging from increased proportions of fungal (e.g. Klironomos et al., 1996; Rillig et al., 1999; Zak et al. 2000; Rønn et al. 2002; Carney et al., 2007) or bacterial biomarker PLFAs (Montealegre et al., 2002; Sonnemann and Wolters, 2005; Drissner et al., 2007) to no effects at all on microbial community structure (Zak et al., 1996; Niklaus et al., 2003; Ebersberger et al., 2004). Possible causes for these discrepancies include the variety in analysis methods and the type of $\mathrm{CO}_{2}$ fumigation systems used in different studies, as well as the presence of different plant species, diverse soil conditions, and variation in microbial communities colonizing the rhizosphere in different ecosystems. Moreover, most of these studies have assessed the effects of elevated $\mathrm{CO}_{2}$ on the composition of the total microbial community, including both metabolically-active and inactive soil microbial communities. Specific information on the responses to elevated $\mathrm{CO}_{2}$ of only those microbial community structures that are actively involved in organic matter transformations is crucial in order to better predict how key biogeochemical processes will function in an environment with increasing $\mathrm{CO}_{2}$ concentrations.

The combination of ${ }^{13} \mathrm{C}$ stable isotope and PLFA analysis through gas chromatography - combustion - isotope ratio mass spectrometry (GC-C-IRMS) has made it possible to trace the flow of $\mathrm{C}$ from a ${ }^{13} \mathrm{C}$-labeled substrate into the PLFA fraction of native microbial communities (Boschker et al., 1998), and to identify the microbial communities actively assimilating the labeled substrate-derived C. Stable isotope probing (SIP) of PLFA has been successfully attained through laboratory incubations with ${ }^{13} \mathrm{C}$ enriched substrate additions (e.g. Waldrop and Firestone, 2004; McMahon et al., 2005; Williams et al., 2006) as well as in-situ through ${ }^{13} \mathrm{C}-\mathrm{CO}_{2}$ pulse-labeling of growing plants (Butler et al., 2003; Treonis et al., 2004; Prosser et al., 2006; Lu et al., 2007). By using in-situ PLFA-based SIP analyses, several studies have demonstrated a dominant contribution of fungi in the immediate assimilation of rhizosphere-derived C (But- ler et al., 2003; Treonis et al., 2004; Olsson and Johnson, 2005).

Phillips et al. (2002) was the first to introduce the PLFAbased SIP technique in elevated $\mathrm{CO}_{2}$ research through a laboratory incubation with ${ }^{13} \mathrm{C}$ enriched substrates added to FACE soils. In their study, elevated $\mathrm{CO}_{2}$ increased fungal metabolism of ${ }^{13} \mathrm{C}$-labeled plant-derived cellobiose. Billings and Ziegler (2005) were the first to trace in-situ the ${ }^{13} \mathrm{C}$ depleted signature of supplemental $\mathrm{CO}_{2}$ into PLFAs in the Duke-FACE experimental forest sites, excluding any potentially confounding effects of ${ }^{13} \mathrm{C}$ additions in the laboratory (cf. Phillips et al., 2002). Although the results from their study indicated clear differences in ${ }^{13} \mathrm{C}$-depleted tracer incorporation among the different microbial groups in the elevated $\mathrm{CO}_{2}$ soils, the effect of elevated $\mathrm{CO}_{2}$ on the metabolicallyactive microbial communities could not be assessed, as the control plots (the case in all FACE experiments) did not receive an equivalent ${ }^{13} \mathrm{C}$ depleted tracer. A more conclusive test of $\mathrm{CO}_{2}$ effects on substrate utilization by specific microbial groups would require the use of an identical ${ }^{13} \mathrm{C}$ tracer incorporated in both elevated $\mathrm{CO}_{2}$ and control plots.

In this study, we combined microbial community PLFA analyses with an in-situ ${ }^{13} \mathrm{C}-\mathrm{CO}_{2}$ pulse-labeling approach in grassland sites from the long-term Giessen FACE experiment in order to (1) identify the microbial groups that are actively metabolizing recently produced rhizosphere-substrate in grassland ecosystems in a $\mathrm{CO}_{2}$ enriched environment, and (2) elucidate which communities are most sensitive in their activity to elevated $\mathrm{CO}_{2}$. To our knowledge, this is the first study assessing in-situ the effect of elevated $\mathrm{CO}_{2}$ on active microbiota in grassland ecosystems through PLFA-SIP in long-term FACE experiments. The main hypothesis was that elevated $\mathrm{CO}_{2}$ would have a larger impact on the activity of fungi, in particular mycorrhizal fungi, compared to bacterial communities due to the dominant role of fungi in rhizosphere carbon assimilation.

\section{Material and methods}

\section{Research site description and ${ }^{13} \mathrm{C}-\mathrm{CO}_{2}$ pulse-labeling}

The effect of elevated $\mathrm{CO}_{2}$ concentration on active soil microbial communities was studied in permanent grassland soils from the University of Giessen long-term Free Air Carbon dioxide Enrichment experiment (GiFACE), which is located at the "Environmental Monitoring and Climate Impact Research Station Linden" near Giessen (Germany) at $50^{\circ} 32^{\prime} \mathrm{N}$ and $8^{\circ} 41^{\prime} \mathrm{E}$ and at an elevation of $172 \mathrm{~m}$ a.s.l. The GiFACE experiment was established in 1998 to study the responses of a semi-natural wet grassland ecosystem to elevated $\mathrm{CO}_{2}$. The extensively managed grassland (fertilization was $40 \mathrm{~kg} \mathrm{~N} \mathrm{ha}^{-1} \mathrm{yr}^{-1}$ since 1995) has not been ploughed for at least 100 years, but is mown twice a year since 1993. The mean annual precipitation and air temperature are $586 \mathrm{~mm}$ 
and $9.3^{\circ} \mathrm{C}$, respectively. The soil is a Fluvic Gleysol with a texture of sandy clay loam over a clay layer (FAO classification). The vegetation was dominated by an Arrhenatheretum elatioris (Br.-B1.) Filipendula ulmaria sub-community vegetation. A detailed description of the experimental site and the GiFACE system is provided by Jäger et al. (2003).

In September 2005, a ${ }^{13} \mathrm{C}_{-} \mathrm{CO}_{2}$ pulse-labeling was conducted on plot $\mathrm{E} 4$ and plot $\mathrm{K} 4$ of the GiFACE experiment. Ours is the first study to apply in-situ pulse-labeling in a FACE experiment. Plot $\mathrm{K} 4$ is naturally exposed to "ambient" $\mathrm{CO}_{2}$ concentrations and $\mathrm{E} 4$ is experimentally exposed to "elevated" $\mathrm{CO}_{2}$ concentrations at $50 \%$ above ambient levels. Since the start of the GiFACE experiment, the "elevated" E4 plot has been exposed to $\mathrm{CO}_{2}$ with a more depleted $\delta^{13} \mathrm{C}$ signature (i.e. $-25 \%$ o between 1998 and June 2004, and -48\%o after June 2004) compared to the $\mathrm{CO}_{2}$ to which the "ambient" K4 plot was exposed (-8\%o). The two pulse-labeling events were performed on two consecutive days under similar weather conditions, each for a period of $6 \mathrm{~h}$. The pulselabeling consisted of an automated supply of ${ }^{13} \mathrm{CO}_{2}$ through acidifying ${ }^{13} \mathrm{C}$-labeled $\mathrm{Na}_{2} \mathrm{CO}_{3}$ (99 atom\%) to photosynthesizing grasses inside a plexiglass chamber $(0.4 \times 0.4 \times 0.5 \mathrm{~m})$ placed on top of a stainless-steel frame. This frame was inserted into the plots a few weeks prior to the start of pulselabeling in order to minimize disturbance-induced soil respiration during the pulse-labeling. The $\mathrm{CO}_{2}$ concentration inside the chamber was controlled and maintained at concentrations corresponding to those naturally occurring at the "ambient" K4 plot and those experimentally controlled at the "elevated" E4 site.

Each pulse-labeling experiment was only conducted in one elevated $\mathrm{CO}_{2}$ and one control treatment plot. These two plots (K4 and E4) are not part of the known replicated treatment design at GiFACE, as described by Jäger et al. (2003), for long-term monitoring of ecosystem responses to elevated $\mathrm{CO}_{2}$. Our pulse-labeling experiment was conducted as a first pulse-labeling trial on plots $\mathrm{K} 4$ and $\mathrm{E} 4$ because of the specific designation of these plots to destructive sampling for soil process-level research at GiFACE. Each pulse-labeling was performed on only one site within each plot due to concerns about the preservation of the natural state of the GiFACE grasslands and the limited size of these plots $(8 \mathrm{~m}$ inner diameter). The GiFACE is the only existing long-term elevated $\mathrm{CO}_{2}$ experiment in a semi-natural temperate wet grassland. Destructive sampling and isotope inputs from pulse-labeling experiments are therefore not favored. Since ours is the first study to apply this type of in-situ pulse-labeling in a FACE experiment, the results of this experiment, though not conclusive for real treatment effects, should be interpreted as to demonstrate the effectiveness of combining in-situ ${ }^{13} \mathrm{C}$ pulselabeling with PLFA analysis to investigate in-situ alterations in the microbial use of rhizosphere-C in response to elevated $\mathrm{CO}_{2}$ by focusing on the members actively involved.

\subsection{Soil sampling}

Soil samples were taken at the $0-7.5 \mathrm{~cm}$ depth from three locations in each pulse-labeled plot at $3 \mathrm{~h}$ and $10 \mathrm{~h}$ after the start of the pulse-labeling to investigate the short-term incorporation of new rhizosphere-C into microbial communities. Soil samples were also taken from the same pulse-labeled plots 11 months later (i.e. August 2006) to determine any long-term retention of ${ }^{13} \mathrm{C}$ label in root, soil and microbial biomass and to assess possible rhizosphere- $\mathrm{C}$ transfer pathways through different microbial communities over time. Soil samples were also taken prior to the pulse-labeling (control samples). For the $3 \mathrm{~h}$ sampling time, the chambers were temporarily removed and, after soil sampling, re-installed for a second period of pulse-labeling. The three samples were mixed to one composite sample per plot. All samples were immediately stored on dry ice and transported to the laboratory. Subsamples used for PLFA-extraction were stored at $-80^{\circ} \mathrm{C}$. Prior to PLFA-extraction, the samples were thawed and sieved through a $2 \mathrm{~mm}$ sieve to remove all visible roots, macro fauna and fresh litter since plants contain large concentrations of the universal PLFA 16:0 and fungal biomarker PLFA 18:2 $\omega 6,9 \mathrm{c}$ (Zelles, 1997). Any remaining visible root material was removed with forceps. The roots of each sample as well as $2 \mathrm{~mm}$ sieved soil subsamples were ball-milled to a fine powder and analyzed for total $\mathrm{C}$ and $\delta^{13} \mathrm{C}$ analysis using an Elemental Analyzer (ANCA-SL, PDZ Europa, UK) connected to an Isotope Ratio Mass Spectrometer (Model 20-20, Sercon, UK) (EA-IRMS).

\subsection{Phospholipid fatty acid extraction and quantification}

The extraction and derivatization of PLFAs for compoundspecific $\delta^{13} \mathrm{C}$ analysis was adapted from Bossio and Scow (1995). Briefly, $6 \mathrm{~g}$ soil samples were extracted in duplicate using chloroform/methanol/phosphate-buffer at a 1:2:1 ratio. Total lipids, retrieved in the chloroform phase, were partitioned on silica gel columns by sequential elution with chloroform, acetone, and methanol. The polar lipid fraction, eluting with methanol, was then subjected to mild alkaline transesterification (using methanolic $\mathrm{KOH}$ ) to form fatty acid methyl esters (FAMEs) which were subsequently analyzed by capillary gas chromatographycombustion-isotope ratio mass spectrometry (GC-C-IRMS)

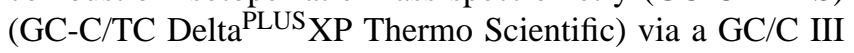
interface. All samples were run in splitless mode and at an injector temperature of $250^{\circ} \mathrm{C}$, using a CP-SIL88 column $(100 \mathrm{~m} \times 0.25 \mathrm{~mm}$ i.d. $\times 0.2 \mu \mathrm{m}$ film thickness; Varian Inc.) with a He flow rate of $1 \mathrm{ml} \mathrm{min}^{-1}$. The oven temperature was programmed at $75^{\circ} \mathrm{C}$ for $2 \mathrm{~min}$, followed by a ramp at $5^{\circ} \mathrm{C} \mathrm{min}^{-1}$ to $180^{\circ} \mathrm{C}$ with a $20 \mathrm{~min}$ hold, and a final ramp at $2^{\circ} \mathrm{C} \mathrm{min}^{-1}$ to $225^{\circ} \mathrm{C}$ with a $20 \mathrm{~min}$ hold. Each soil extract was run in duplicate on the GC-C-IRMS to ensure reliable mean $\delta^{13} \mathrm{C}$ values. The average chromatographic peak area and $\delta^{13} \mathrm{C}$ value was used in all calculations. 


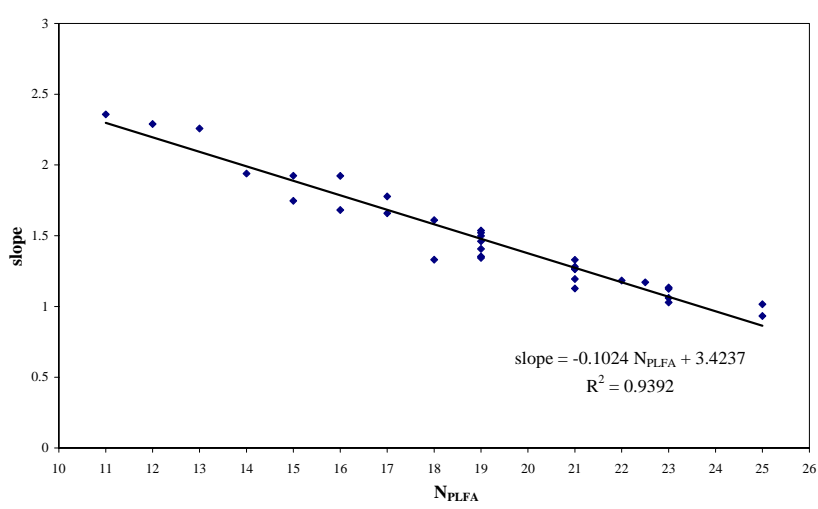

Fig. 1. The relationship between the number of $\mathrm{C}$ atoms of PLFA components (N $\mathrm{NLFA}_{\text {) }}$ ) and their corresponding slope, obtained from linear regressions through the origin between the chromatographic peak areas and concentrations of individual standard FAMEs of the quantitative "37 Component FAME Mix" (\# 47885, Supelco Inc.).

Prior to GC-C-IRMS analysis, a mixture of two internal standards (12:0 and 19:0) was added to the FAME extract. Individual fatty acids were identified based on relative retention times vs. the two internal standards and crossreferenced with several standards: a mixture of 37 FAMEs (37 Component FAME Mix, \# 47885, Supelco Inc.), a mixture of 24 FAMEs (BAME mix, \# 47080, Supelco Inc.) and several individual FAMEs (12:0, 13:0, 19:0, a16:0, a17:0, $16: 1 \omega 7 \mathrm{c}, 16: 1 \omega 7 \mathrm{t}, 18: 1 \omega 7 \mathrm{c}, 18: 1 \omega 11 \mathrm{c}, 18: 2 \omega 6,9 \mathrm{c}, 10 \mathrm{Me}-$ 16:0, 10Me-18:0, 20:5 $\omega 3$, Supelco Inc. and Larodan Inc.). On average, 25 PLFA peaks were detected and quantified, but only 16 were selected for ${ }^{13} \mathrm{C}$ analysis because of their use as biomarker fatty acids for different microbial communities (Zelles, 1997). The biomarker PLFAs analyzed within this dataset included: $18: 1 \omega 9 \mathrm{c}$ and $18: 2 \omega 6,9 \mathrm{c}$ (indicative of fungi), 16:1 $\omega 5$ (indicative of arbuscular mycorrhizal fungi), i14:0, i15:0, a15:0, i16:0, i17:0, a17:0 (indicative of gram-

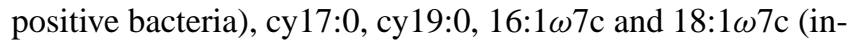
dicative of gram-negative bacteria) and 10Me PLFAs (indicative of actinomycetes) (Harwood and Russell, 1984; Kroppenstedt, 1985; Brennan, 1988; Vestal and White, 1989; Olsson et al., 1995; Frostegård and Bååth, 1996; Stahl and Klug, 1996; Zelles, 1997). These PLFAs comprised approximately 90\% of the total PLFA-C concentration. We determined the ratios of the peak area of each individual PLFA to that of 16:0, a universal PLFA occurring in the membranes of all organisms. PLFA ratios less than 0.02 were excluded from the data set (cf. Drijber et al., 2000). The carbon concentrations of the individual biomarker PLFAs in the soil extracts were quantified using the quantitative " 37 Component FAME Mix" which was run in a dilution series. For each individual standard FAME, a linear regression through the origin was performed between the chromatographic peak areas and known concentrations (ranging from 5 to $150 \mathrm{ng} \mu \mathrm{l}^{-1}$ ). For each linear regression, a unique slope was obtained for each individual standard FAME, which decreased with increasing number of $\mathrm{C}$ atoms. The different slopes were plotted as a function of the number of $\mathrm{C}$ atoms of the PLFAs which gave a negative correlation with $R^{2}=0.94$ (Fig. 1). Using this correlation, the $\mathrm{C}$ concentration of each of the individual PLFAs in the soil extract could be quantified as follows:

$[\mathrm{PLFA}-\mathrm{C}]=\frac{\mathrm{PA}}{\text { slope }}$

with [PLFA-C] $=$ the $\mathrm{C}$ concentration of each PLFA in mmol PLFA-C $1^{-1}, \mathrm{PA}=$ the chromatographic peak area $(\mathrm{Vs})$ of the individual PLFA, and slope = the slope of the linear regression through the origin between the peak areas and concentrations of the individual PLFA. Quantification of chromatographic PLFA peak areas through GC-C-IRMS has also been done by others, but only by using one or two quantitative FAME standards, in most cases 12:0, 13:0 or 19:0 (e.g. Bouillon et al., 2004; Williams et al., 2006). Our quantitative analysis shows that PLFA concentrations could be greatly over- or underestimated when working with only one or two standards. For treatment comparisons, PLFA-C concentrations were expressed as nmol PLFA-C $\mathrm{g}^{-1}$ soil.

\subsection{Carbon-13 phospholipid fatty acid analysis}

The $\delta^{13} \mathrm{C}$ values of the individual FAMEs obtained from the GC-C-IRMS were corrected for the addition of the methyl group during transesterification by simple mass balance:

$\delta^{13} \mathrm{C}_{\text {PLFA }}=\frac{\left[\left(\mathrm{N}_{\text {PLFA }}+1\right) \delta^{13} \mathrm{C}_{\mathrm{FAME}}-\delta^{13} \mathrm{C}_{\mathrm{MeOH}}\right]}{\mathrm{N}_{\text {PLFA }}}$

where NPLFA refers to the number of $\mathrm{C}$ atoms of the PLFA component, $\delta^{13} \mathrm{C}_{\mathrm{FAME}}$ is the $\delta^{13} \mathrm{C}$ value of the FAME after transesterification, and $\delta^{13} \mathrm{C}_{\mathrm{MeOH}}$ is the $\delta^{13} \mathrm{C}$ value of the methanol used for transesterification $(-36.7 \pm 0.4 \%$ ovs. Pee Dee Belemnite by EA-IRMS using Chromosorb-W; $n=20$ ).

Carbon-13 enrichment (expressed as $\Delta \delta^{13} \mathrm{C}$ ) was calculated by subtracting the pre-labeling (control) natural abundance PLFA $\delta^{13} \mathrm{C}$ values from the post-labeling PLFA $\delta^{13} \mathrm{C}$ values for the $3 \mathrm{~h}$ and $10 \mathrm{~h}$ samples. In each treatment plot, an unlabeled area was also sampled after 11 months and used as a control to calculate the ${ }^{13} \mathrm{C}$ enrichment of the 11 month PLFAs.

To assess the effect of elevated $\mathrm{CO}_{2}$ on the $\mathrm{C}$-assimilating activities of the different microbial communities, we calculated the percentage ${ }^{13} \mathrm{C}$ enrichment of individual biomarker PLFAs relative to the enrichment in ${ }^{13} \mathrm{C}$ of the universal 16:0 PLFA after $10 \mathrm{~h}$ (cf. Butler et al., 2003; Lu et al., 2007), to correct for any differences in pulse-labeling efficiency and total amount of ${ }^{13} \mathrm{C}$ uptake among the two pulse-labeling events.

\subsection{Statistical analysis and error analysis}

Since only one physical soil sample (comprised of a composite of 3 soil samples and extracted and analyzed in dupli- 
Table 1. $\delta^{13} \mathrm{C}$ values and $\delta^{13} \mathrm{C}$ enrichment $\left(\Delta \delta^{13} \mathrm{C}\right.$, i.e. net increase relative to natural abundance $\delta^{13} \mathrm{C}$ values of soil and roots from nonlabeled control plots) for soil and root C. $\delta^{13} \mathrm{C}$ measurements were done on composite $0-7.5 \mathrm{~cm}$ soil samples from 3 sampling points per pulse-labeled plot.

\begin{tabular}{ccccccccc}
\hline & \multicolumn{7}{c}{ Non-labeled } & \multicolumn{7}{c}{ Pulse-labeled } \\
\hline & \multicolumn{2}{c}{ control } & \multicolumn{2}{c}{$3 \mathrm{~h}$} & \multicolumn{2}{c}{$10 \mathrm{~h}$} & \multicolumn{2}{c}{11 months } \\
\hline & $\mathrm{K} 4$ & $\mathrm{E} 4$ & $\mathrm{~K} 4$ & $\mathrm{E} 4$ & $\mathrm{~K} 4$ & $\mathrm{E} 4$ & $\mathrm{~K} 4$ & $\mathrm{E} 4$ \\
\hline & & & \multicolumn{7}{c}{$\delta^{13} \mathrm{C}(\%)$} \\
\hline Root C & -30.0 & -35.2 & 13.2 & 3.3 & 31.0 & -12.4 & -9.1 & -13.0 \\
Soil C & -28.0 & -30.4 & -26.7 & -27.9 & -17.4 & -26.5 & -25.9 & -27.8 \\
\hline & & & & $\Delta \delta^{13} \mathrm{C}(\%)$ & & & \\
\hline Root C & & & 43.2 & 38.5 & 61.0 & 22.8 & 21.0 & 22.1 \\
Soil C & & & 1.3 & 2.5 & 10.6 & 3.2 & 2.1 & 1.9 \\
\hline
\end{tabular}

cate) represented one treatment plot and sampling time, our statistical analyses, performed by a two-sample $t$-test $(n=2$, from duplicate extractions), can only indicate whether there are any significant differences between the treatments within the analytical error associated with the extraction method and IRMS analysis.

To obtain an indication of the error associated with the PLFA-extraction method, three replicate PLFA-extractions were performed on one unlabeled $0-7.5 \mathrm{~cm}$ soil sample from the $\mathrm{K} 4$ plot. In terms of PLFA-C concentration (ng PLFA$\mathrm{Cg}^{-1}$ soil), an average $\% \mathrm{CV}$ of $4.5 \pm 5.8 \%$ was obtained across 25 quantified PLFAs. In terms of $\delta^{13} \mathrm{C}$, an average standard deviation of $0.7 \pm 0.7 \%$ o was obtained. To get an idea of the precision of the GC-C-IRMS analysis, each of the three extracts was run in duplicate on the GC-C-IRMS. In terms of PLFA-C concentration, the average \% CV for the duplicate extracts was $3.4 \pm 2.1 \%$. The average standard deviation of the mean $\delta^{13} \mathrm{C}$ of each two duplicate extracts was $0.7 \pm 0.8 \%$ o.

\section{Results and discussion}

\section{1 ${ }^{13} \mathrm{C}$ enrichment of root biomass and soil $\mathrm{C}$}

Both the pulse-labeling in plot $\mathrm{K} 4$ as in plot $\mathrm{E} 4$ resulted in a rapid increase in the $\delta^{13} \mathrm{C}$ signature of the root biomass and soil $\mathrm{C}$ (Table 1). Root biomass as well as soil $\mathrm{C}$ was still enriched in ${ }^{13} \mathrm{C}$ relative to the non-labeled soil samples 11 months post-labeling. $\delta^{13} \mathrm{C}$ signatures of soil and root biomass were lower (i.e. more negative or less positive) in plot E4 compared to K4 in pre- as well as post-labeling samples, which reflected the incorporation of the depleted ${ }^{13} \mathrm{C}$ signature of the $\mathrm{CO}_{2}$ used for the $\mathrm{CO}_{2}$ fumigation in plot $\mathrm{E} 4$ since 1998 (i.e. -25\%o between 1998 and June 2004, and 48 after June 2004). Therefore, the data was presented as
${ }^{13} \mathrm{C}$ enrichment $\left(\Delta \delta^{13} \mathrm{C}\right.$ ) relative to unlabeled (control) samples to correct for these initial ${ }^{13} \mathrm{C}$ differences. However, even after this correction, the $\delta^{13} \mathrm{C}$ enrichment of soil and root biomass was generally greater in the $\mathrm{K} 4$ compared to the E4 plot. Possible soil $\mathrm{CO}_{2}$ release due to physical disturbance at the $3 \mathrm{~h}$ soil sampling could have resulted in a greater isotopic dilution of the ${ }^{13} \mathrm{CO}_{2}$ in the labeling chamber of plot $\mathrm{E} 4$ which had a more depleted $\delta^{13} \mathrm{C}$ signature of soil gas $\mathrm{CO}_{2}(\sim-27.8 \%$ o $)$ compared to the $\mathrm{K} 4$ plot $(\sim-24.2 \%$ ) (K. Lenhart, unpublished results). Because of these differences in net ${ }^{13} \mathrm{C}$ incorporation into the rhizosphere of the two plots, ${ }^{13} \mathrm{C}$-PLFA comparisons between $\mathrm{K} 4$ and $\mathrm{E} 4$ were made after expressing the data as percentages of ${ }^{13} \mathrm{C}$ enrichment of each PLFA relative to the enrichment in ${ }^{13} \mathrm{C}$ of the 16:0 PLFA of the soil, which is ubiquitous in cell membranes of all organisms.

4.2 Rhizosphere-C uptake and translocation within microbial communities

Soil samples taken $3 \mathrm{~h}$ after the start of the pulse-labeling showed only very limited ${ }^{13} \mathrm{C}$ enrichment in the different biomarker PLFAs in the K4 and E4 plots (Fig. 2). After $10 \mathrm{~h}$, a very large incorporation of ${ }^{13} \mathrm{C}$ was observed in the general fungal PLFAs $(18: 1 \omega 9 \mathrm{c}, 18: 2 \omega 6,9 \mathrm{c})$ and arbuscular mycorrhizal fungal (AMF) PLFA (16:1 $\omega 5)$, while remaining low for the bacterial PLFAs. This suggested that both nonarbuscular mycorrhizal fungi as well as AMF are closely associated with the root system in grassland soils (Butler et al., 2003) and actively utilize and incorporate newly produced rhizosphere-C into their biomass, while other microbial communities were active in metabolizing other sources of $\mathrm{C}$. The importance of fungi in assimilating fresh plant-derived $\mathrm{C}$ has been demonstrated in various ecosystems based on high amounts of ${ }^{13} \mathrm{C}$ incorporation from a variety of substrates into the general fungal biomarker PLFA C18:2 $\omega 6,9 \mathrm{c}$ (Arao, 

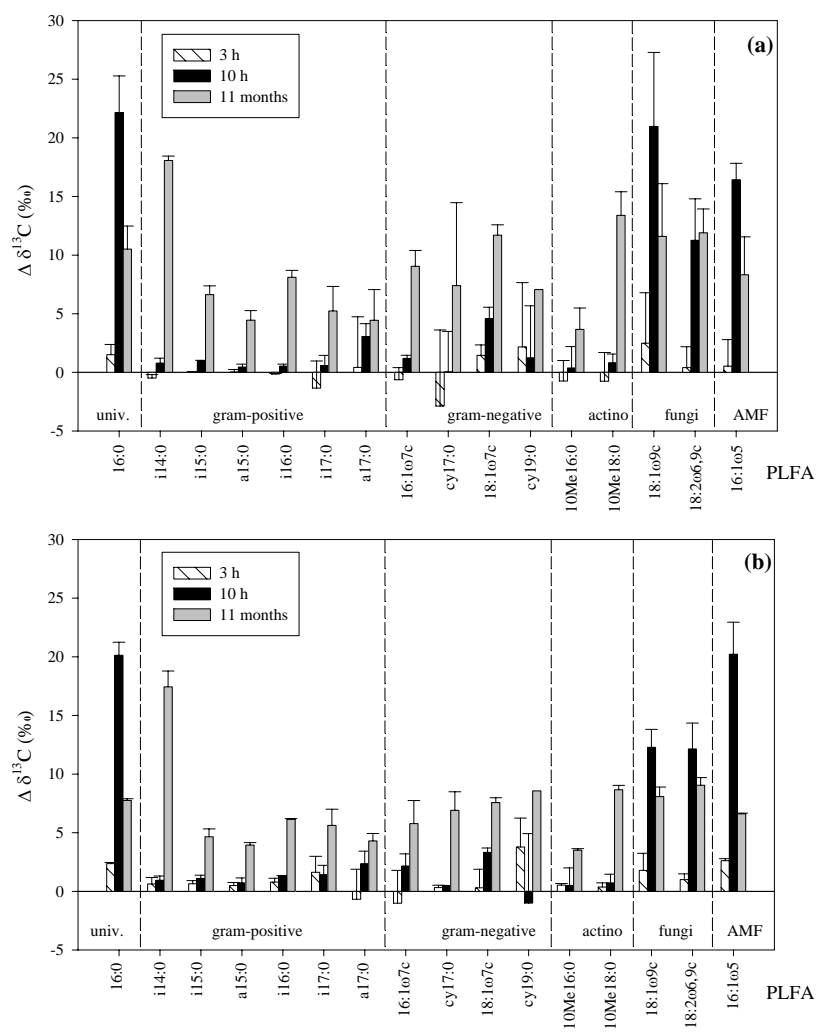

Fig. 2. Net increase of $\delta^{13} \mathrm{C}$ values of individual biomarker PLFAs extracted from pulse-labeled $0-7.5 \mathrm{~cm}$ soil samples from plots $\mathrm{K} 4$ (a) and E4 (b) sampled $3 \mathrm{~h}, 10 \mathrm{~h}$ and 11 months post-labeling, in excess of those in the non-labeled control plots. Univ. = universal biomarker PLFA; gram-positive = gram-positive bacteria; gramnegative $=$ gram-negative bacteria $;$ actino $=$ actinomycetes; $\mathrm{AMF}=$ arbuscular mycorrhizal fungi. Figure bars and error bars represent means and mean deviations of two subsamples from one composite soil sample of each pulse-labeled site (E4 and K4) at each sampling time ( $3 \mathrm{~h}, 10 \mathrm{~h}$ and 11 months).

1999; Butler et al., 2003; Waldrop and Firestone, 2004; Lu et al., 2007). Recent in-situ studies using PLFA-based SIP by ${ }^{13} \mathrm{C}-\mathrm{CO}_{2}$ pulse-labeling have also reported a much faster incorporation of rhizosphere- $\mathrm{C}$ into fungal (Treonis et al., 2004) as well as AMF biomass (Johnson et al., 2002; Olsson and Johnson, 2005) compared to bacterial biomass (Treonis et al., 2004).

The $\delta^{13} \mathrm{C}$ enrichment in all identified fungal PLFAs was still largely present after 11 months but had decreased relative to the enrichment observed after $10 \mathrm{~h}$ (Fig. 2). This decrease in fungal PLFA- ${ }^{13} \mathrm{C}$ enrichment between $10 \mathrm{~h}$ and 11 months was probably caused by a dilution from new unlabeled rhizosphere-C assimilation during continued photosynthesis in the 11 month period following the pulselabeling. Interestingly, 11 months after the pulse-labeling events, much higher amounts of ${ }^{13} \mathrm{C}$ had been incorporated in the bacterial PLFAs at both $\mathrm{K} 4$ and E4 plots compared to the $3 \mathrm{~h}$ and $10 \mathrm{~h}$ post-labeling times. These results are consistent with the results of Olsson and Johnson (2005) who found over a time period of 32 days a decrease in the ${ }^{13} \mathrm{C}$ enrichment of AMF PLFA 16:1 $\omega 5$, extracted from roots, and a concomitant increase in ${ }^{13} \mathrm{C}$ enrichment of bacterial PLFAs extracted from soil. Our data suggests that fungi play a major role in the $\mathrm{C}$ flux from roots into soil microbial biomass. It can be postulated that the rapidly assimilated new rhizosphere-C by fungi is over time retracted from degenerating fungal hyphae and becomes incorporated into bacterial biomass. Alternatively, bacterial assimilation of $\mathrm{C}$ derived from fungal necromass or dead root material rather than from living root products (e.g. exudates) might form an alternative explanation for the slower incorporation of ${ }^{13} \mathrm{C}$ into the bacterial PLFAs. Possible differences in preferential substrate use between microbial communities should be further investigated.

The unexpected high ${ }^{13} \mathrm{C}$ enrichment of fungal PLFAs after 11 months might suggest long-term retention of rhizodeposit- $\mathrm{C}$ in fungal biomass, which could be of importance to soil organic $\mathrm{C}$ sequestration in grassland ecosystems. However, as PLFAs are the major components of the cell membranes of living organisms and, crucially, only remain intact in viable cells (White et al., 1979), this would suggest very little activity and extremely slow turnover of fungal biomass, assuming no continued active ${ }^{13} \mathrm{C}$-assimilation in the period following the pulse-labeling. Such slow microbial cell turnover would be in contrast to earlier findings of Treonis et al. (2004) where a decrease in ${ }^{13} \mathrm{C}$ enrichment was found for all PLFAs between 4 and 8 days post-labeling, and root-derived $\mathrm{C}$ turnover was even greater through fungal $(16: 1 \omega 5,18: 1 \omega 9,18: 2 \omega 6,9)$ and gram-negative (16:1 $\omega 7,18: 1 \omega 7$, cy 19:0) bacterial biomarker PLFAs compared to gram-positive bacterial biomarker lipids (15:0a, 15:0i, 16:0i). As for most grassland PLFA studies, the potential contribution of very fine root hairs and sloughed off root cells to the abundance of microbial biomarker

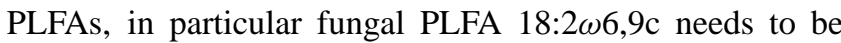
considered, even after thorough sieving and manual removal of roots prior to PLFA analysis. After 11 months, root biomass was also still highly enriched in ${ }^{13} \mathrm{C}$ with enrichment values about double of those of the fungal communities (Table 1 and Fig. 2). However, as pointed out by Treonis et al. (2004), other plant-characteristic PLFAs such as polyenoic fatty acids (i.e. those containing multiple double bonds) (Federle, 1986) would have to be detected in large quantities in case of significant plant contamination of the soil samples. This was not the case in our study. Therefore, we believe that the observed greatest and exclusive incorporation of ${ }^{13} \mathrm{C}$ into fungal PLFAs after $10 \mathrm{~h}$ as well as the long-term retention of the ${ }^{13} \mathrm{C}$ label in the fungal PLFAs after 11 months was a result of rapid $(10 \mathrm{~h})$ and continued (11 months) fungal assimilation or recycling of ${ }^{13} \mathrm{C}$-labeled root-derived $\mathrm{C}$ rather than of ${ }^{13} \mathrm{C}$-labeled plant PLFAs contributing to fungal PLFAs. 
4.3 Effect of elevated $\mathrm{CO}_{2}$ on microbial community structure

Fungal communities have been shown to be highly responsive to increases in rhizosphere-C supply. A study by Griffiths et al. (1999) showed an increase in fungal PLFA $18: 2 \omega 6,9 \mathrm{c}$ when amounts of synthetic root exudates added to soil were increased. Along with the results of our study which indicate that fungi are most actively utilizing rhizodeposits in the GiFACE grasslands (Fig. 2), it was expected that fungal communities are most sensitive in their activity to any responses of plant-C inputs likely to occur under rising atmospheric $\mathrm{CO}_{2}$ concentrations (Rogers et al., 1994). Several studies in N-limited ecosystems found stimulated fungal and AMF activities under elevated $\mathrm{CO}_{2}$ (Rillig et al., 1999; Klironomos et al., 1996; Zak et al., 2000; Treseder, 2004), which were attributed to the greater substrate use efficiency of fungi under N-limiting conditions. Receiving only $40 \mathrm{~kg} \mathrm{Nha}^{-1} \mathrm{yr}^{-1}$, the grassland sites at GiFACE are also considered N-limited. Although in nutrientlimited ecosystems, most aboveground biomass responses to elevated $\mathrm{CO}_{2}$ are weak or even zero (Schäppi and Körner, 1996; Stöcklin et al., 1998; Körner, 2000), an increase in aboveground biomass with elevated $\mathrm{CO}_{2}$ was observed at GiFACE from the third $\mathrm{CO}_{2}$ enrichment year (i.e. 2000) on (Kammann et al., 2005). A stimulated root and mycorrhizal growth and hence nutrient acquisition were believed to be pre-requisite for stimulated aboveground yields at these nutrient-limited sites (Kamman et al., 2005). In our study, no differences were found in the amount of PLFA-C of the individual biomarker PLFAs between elevated and ambient $\mathrm{CO}_{2}$ treatments (Fig. 3). Similarly, other studies were also unable to detect changes in microbial biomass (Allen et al., 2000; Kandeler et al., 2006) nor shifts between bacterial and fungal communities under elevated $\mathrm{CO}_{2}$ (Zak et al., 1996; Rønn et al., 2002; Niklaus et al., 2003; Ebersberger et al., 2004). Several studies have even shown a strong response of bacteria (Sonnemann and Wolters, 2005) and an enrichment of gram-negative bacteria in particular under elevated $\mathrm{CO}_{2}$ (Montealegre et al., 2002; Drissner et al., 2007), while the fungal biomass did not change. Until now, in-situ microbial community structural analyses in FACE studies have been limited to total PLFA-C distribution examinations which do not distinguish between the metabolically-active versus inactive rhizosphere microbial communities. The advantage of a pulse-labeling approach in combination with ${ }^{13}$ C-PLFA analysis is the additional information obtained on the response of those microbial communities that are actively assimilating newly produced rhizosphere-C. The response to elevated $\mathrm{CO}_{2}$ of metabolically-active microbial communities may be undetectable through conventional total PLFA$\mathrm{C}$ analyses due to the large background concentration of the mostly inactive total soil microbial community, but is of importance to better understand $\mathrm{C}$ cycling in terrestrial ecosystems under increasing $\mathrm{CO}_{2}$ concentrations.

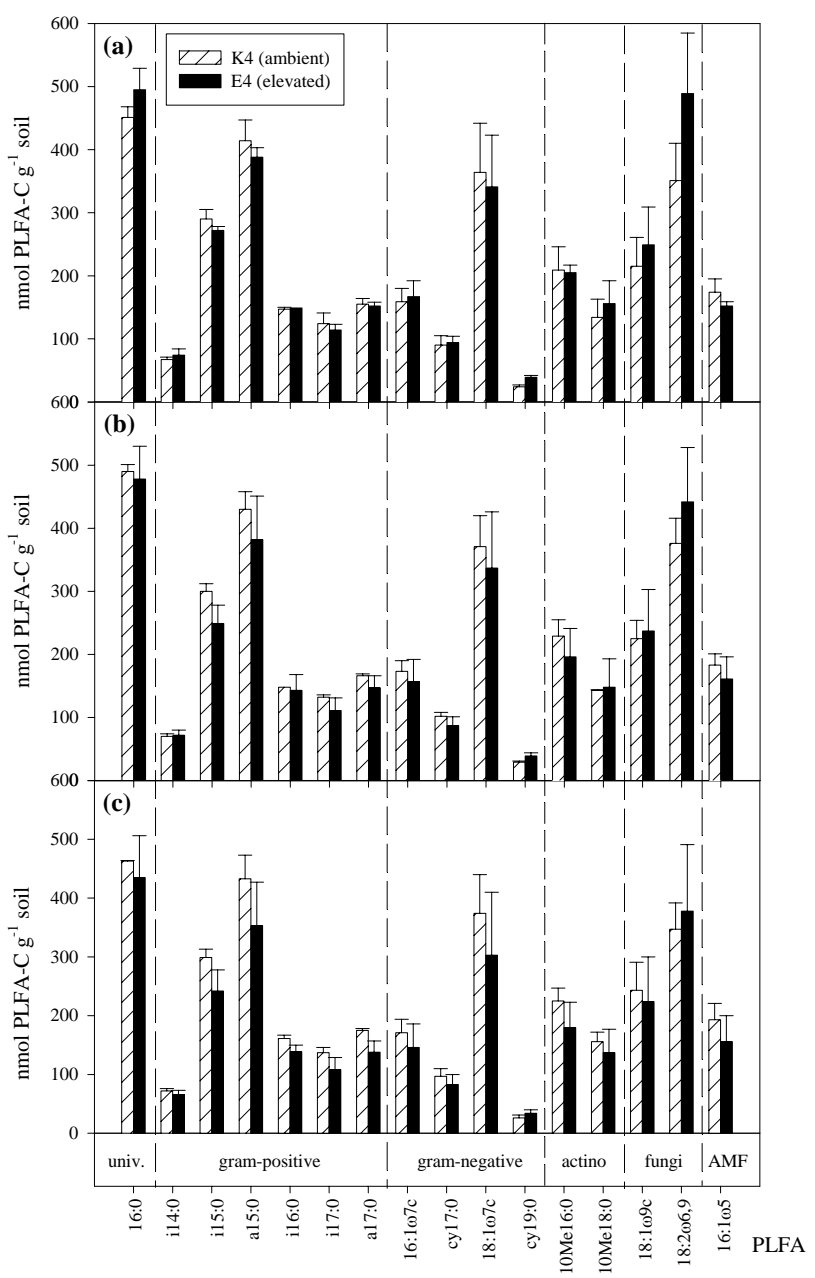

Fig. 3. Mean PLFA-C concentrations of individual biomarker PLFAs in 0-7.5 cm soil samples from plots K4 and E4 sampled after $3 \mathrm{~h}$ (a), $10 \mathrm{~h}$ (b), and 11 months (c). Univ. = universal biomarker PLFA; gram-positive $=$ gram-positive bacteria; gram-negative $=$ gram-negative bacteria; actino = actinomycetes; $\mathrm{AMF}=$ arbuscular mycorrhizal fungi. Figure bars and error bars represent means and mean deviations of two subsamples from one composite soil sample of each pulse-labeled site (E4 and K4) at each sampling time ( $3 \mathrm{~h}, 10 \mathrm{~h}$ and 11 months). Values were not significantly different between K4 and E4 (based on two-sample $t$-test, $n=2$ ).

Our ${ }^{13} \mathrm{C}$-PLFA results indicated greater proportional ${ }^{13} \mathrm{C}$ enrichment relative to $16: 0$ for the AMF PLFA 16:1 $\omega 5$ $(P=0.057)$ in the elevated compared to ambient $\mathrm{CO}_{2}$ treatment, while the opposite was observed for the fungal 18:1 $\omega 9$ c PLFA ( $P=0.100$ ) (Fig. 4$)$. The ${ }^{13}$ C proportional enrichment of the general fungal biomarker PLFA $18: 2 \omega 6,9 \mathrm{c}$ as well as of bacterial PLFAs remained unaffected by elevated $\mathrm{CO}_{2}$, except for i16:0, a gram-positive bacterial biomarker PLFA, which showed a significant increase in its proportional ${ }^{13} \mathrm{C}$ enrichment under elevated $\mathrm{CO}_{2}(P=0.041) . \quad 18: 1 \omega 9 \mathrm{c}$ and/or 18:2 $\omega 6,9 \mathrm{c}$ are frequently used to indicate the presence 


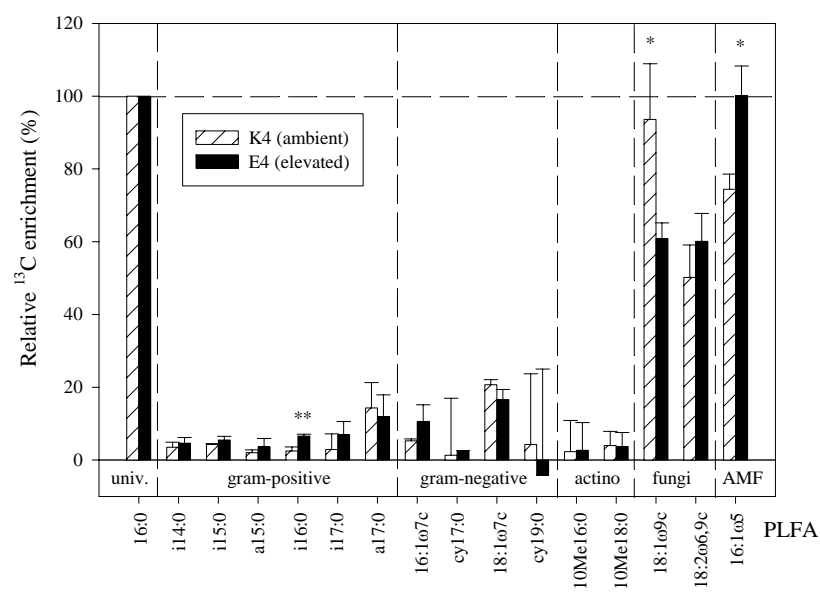

Fig. 4. Mean percentages of ${ }^{13} \mathrm{C}$ enrichment of individual biomarker PLFAs relative to the enrichment in ${ }^{13} \mathrm{C}$ of the universal 16:0 PLFA in 0-7.5 cm soil samples from plots K4 and E4 sampled after $10 \mathrm{~h}$. Figure bars and error bars represent means and mean deviations for two subsamples from one composite soil sample of each pulse-labeled site (E4 and K4). * and ** indicate statistical differences at $P<0.1$ and $P<0.05$ respectively (based on two-sample $t$-test, $n=2$ ).

of non-arbuscular mycorrhizal fungi (Phillips et al., 2002; Rønn et al., 2002; Fierer et al., 2003; Treonis et al., 2004; Chung et al., 2007; Drissner et al., 2007). Though some-

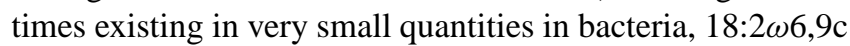
has been demonstrated to be a valid biomarker for eukaryotes (Frostegård and Bååth, 1996; Zelles, 1997). Therefore, when plant contamination of the PLFA profile is limited, 18:2 $\omega 6,9 \mathrm{c}$ can be considered a valid biomarker for fungal biomass. Less certainty exists about the uniqueness of the $18: 1 \omega 9 \mathrm{c}$ PLFA as a fungal membrane fatty acid, since it has also been found in cultured bacterial cells (Zelles, 1997). This questions the general use of this fatty acid as a common biomarker for fungal biomass in other studies (e.g. Treonis et al., 2004; Chung et al., 2007; Drissner et al., 2007). On the other hand, a strong and rapid $(10 \mathrm{~h})$ enrichment in ${ }^{13} \mathrm{C}$ was detected in 16:1 $\omega 5,18: 2 \omega 6,9 \mathrm{c}, 18: 1 \omega 9 \mathrm{c}$ and 16:0. The latter PLFA is a key intermediate in the metabolic pathways of cellular fatty acid biosynthesis, and therefore expected to show the greatest and most rapid ${ }^{13} \mathrm{C}$ enrichment following pulse-labeling. Since none of the other PLFAs showed similar enrichments in ${ }^{13} \mathrm{C}$ after $10 \mathrm{~h}$ (Fig. 2), we believe that the 18:1 $\omega 9 \mathrm{c}$ PLFA belonged to the same functional group as the $16: 1 \omega 5,18: 2 \omega 6,9 \mathrm{c}$ and therefore likely to be of fungal origin. Consequently, the inconsistent responses of the non-arbuscular mycorrhizal fungal PLFAs $(18: 1 \omega 9 \mathrm{c}$ and $18: 2 \omega 6,9 \mathrm{c})$ to elevated $\mathrm{CO}_{2}$ rather suggest inconsistent fungal species responses to elevated $\mathrm{CO}_{2}$. Unfortunately, PLFA analysis does not allow for specific detection of individual species of the microbial communities. Stable isotope labeling techniques in combination with molecular tools such as
RNA-SIP (Griffiths et al., 2004; Rangel-Castro et al., 2005; Lu et al., 2006) could provide a better resolution of the individual active microbial communities at the species-level and should be explored in FACE research in order to better understand shifts in microbial species composition due to elevated $\mathrm{CO}_{2}$.

Several studies have analyzed the microbial community composition under elevated $\mathrm{CO}_{2}$ using other experimental methods than the PLFA-based SIP approach used in this study, such as extracellular enzyme activity assays (Moscatelli et al., 2005; Chung et al., 2006), PCR-DGGE analyses (Chung et al., 2006), substrate-induced respiration measurements, and 16S rRNA clone libraries (Lipson et al., 2005). Corresponding to our findings, most of these studies also suggested stimulated fungal pathways under increased atmospheric $\mathrm{CO}_{2}$ concentrations. This fungal stimulation could be beneficial for ecosystem functioning as fungi are believed to play a positive role in soil structural stabilization (Bossuyt et al., 2001; Rillig et al., 2002), C sequestration (Treseder and Allen, 2000; Bailey et al., 2002) and N immobilization through hyphal translocation (Beare, 1997; Frey et al., 2000). However, 6 years of experimental $\mathrm{CO}_{2}$ doubling in a sandy scrub-oak ecosystem resulted in a decline in soil carbon despite higher plant growth and increased fungal abundance (Carney et al., 2007). The study by Carney et al. (2007) showed that increased fungal abundance can reduce soil carbon storage possibly by promoting lignolytic enzyme activity and subsequent enhanced priming of recalcitrant organic materials. This could explain the often weak or non-detected increases in soil carbon content in response to elevated $\mathrm{CO}_{2}$ even when plant biomass has increased substantially (e.g., Gill et al., 2002; Jastrow et al., 2005; van Groeningen et al., 2006).

\section{Conclusions}

Using PLFA-SIP, the present study showed a rapid transfer of newly produced rhizosphere- $\mathrm{C}$ to fungal biomass in the surface $0-7.5 \mathrm{~cm}$ soil layer of the investigated grassland sites at GiFACE. This ${ }^{13} \mathrm{C}$ enrichment of fungal PLFAs decreased but was still largely present after 11 months post-labeling. The much slower incorporation of rhizosphere-C into bacterial PLFAs, but their significant ${ }^{13} \mathrm{C}$ enrichment after 11 months further suggests a potential fungi-mediated transfer of rhizosphere- $\mathrm{C}$ to the bacteria from degenerating fungal hyphae, or a preferential bacterial use of dead root or fungal necromass materials as $\mathrm{C}$ source over the direct utilization of fresh root-exudate $\mathrm{C}$. This in-situ pulse-labeling experiment demonstrated for the first time in long-term FACE experimental grasslands stimulated rhizosphere-C utilization by arbuscular mycorrhizal fungi under elevated $\mathrm{CO}_{2}$ through PLFA-based SIP analyses. The observed increase in the proportional ${ }^{13} \mathrm{C}$ enrichment of $\mathrm{AMF} 16: 1 \omega 5$ relative to $16: 0$, but concomitant decrease and lack of change in the propor- 
tional ${ }^{13} \mathrm{C}$ enrichment of $18: 1 \omega 9 \mathrm{c}$ and $18: 2 \omega 6,9 \mathrm{c}$ PLFAs, respectively, under elevated $\mathrm{CO}_{2}$ suggested fungal speciesspecific responses to elevated $\mathrm{CO}_{2}$ while also questioning the general use of $18: 1 \omega 9 \mathrm{c}$ as a true fungal biomarker. Additional pulse-labeling studies in combination with microbial biomarker SIP analyses in the fully-replicated FACE experiment at Giessen, as well as in other long-term FACE experiments are required (1) to test if the results observed in this trial experiment are reproducible both at GiFACE but also at FACE experiments in other ecosystems with different plant species and soil types, and (2) to investigate if these microbial changes persist over time or if microbial acclimation occurs.

Acknowledgements. We thank B. Leroy (UGent), J. Six and A. Kong (UC Davis) for their contribution to a successful setup of the PLFA-extraction method in our own laboratory. E. Gillis is greatly acknowledged for help with the PLFA-extractions. K. Denef acknowledges a post-doctoral fellowship from the Belgian Research Foundation - Flanders.

Edited by: J. Leifeld

\section{References}

Allen, A. S., Andrews, J. A., Finzi, A. C., Matamala, R., Richter, D. D., and Schlesinger, W. H.: Effects of free-air $\mathrm{CO}_{2}$ enrichment (FACE) on belowground processes in a Pinus taeda forest, Ecol. Appl., 10, 437-448, 2000.

Alley, R., Berntsen, T., Bindoff, N. L., Chen, Z., Chidthaisong, A., Friedlingstein, P., Gregory, J., Hegerl, G., Heimann, M., Hewitson, B., Hoskins, B., Joos, F., Jouzel, J., Kattsov, V., Lohmann, U., Manning, M., Matsuno, T., Molina, M., Nicholls, N., Overpeck, J., Qin, D., Raga, G., Ramaswamy, V., Ren, J., Rusticucci, M., Solomon, S., Somerville, R., Stocker, T. F., Stott, P., Stouffer, R. J., Whetton, P., Wood, R. A., and Wratt, D.: Climate change 2007: The Physical Science Basis, Contribution of working group I to the fourth assessment report of the Intergovernmental Panel on Climate Change, Paris, 2007.

Arao, T.: In situ detection of changes in soil bacterial and fungal activities by measuring $13 \mathrm{C}$ incorporation into soil phospholipid fatty acids from ${ }^{13} \mathrm{C}$ acetate, Soil Biol. Biochem., 31, 10151020, 1999.

Beare, M. H.: Fungal and bacterial pathways of organic matter decomposition and nitrogen mineralization in arable soils, in: Soil Ecology in Sustainable Agricultural Systems, edited by: Brussaard, L. and Ferrera-Cerrato, R., Lewis Publishers, Boca Raton, FL, 37-70, 1997.

Bailey, V. L., Smith, J. L., and Bolton, H.: Fungal-to-bacterial ratios in soils investigated for enhanced $\mathrm{C}$ sequestration, Soil Biol. Biochem., 34, 997-1007, 2002.

Billings, S. A. and Ziegler, S. E.: Linking microbial activity and soil organic matter transformations in forest soils under elevated $\mathrm{CO}_{2}$, Global Change Biol., 11, 203-212, 2005.

Boschker, H. T. S., Nold, S. C., Wellsbury, P., Bos, D., de Graaf, W., Pel, R., Parkes, R. J., and Cappenberg, T. E.: Direct linking of microbial populations to specific biogeochemical processes by C-13-labelling of biomarkers, Nature, 392, 801-805, 1998.
Bossio, D. A. and Scow, K. M.: Impact of Carbon and Flooding on the Metabolic Diversity of Microbial Communities in Soils, Appl. Environ. Microbiol., 61, 4043-4050, 1995.

Bossuyt, H., Denef, K., Six, J., Frey, S. D., Merckx, R., and Paustian, K.: Influence of microbial populations and residue quality on aggregate stability, Appl. Soil Ecol., 16, 195-208, 2001.

Bouillon, S., Moens, T., Koedam, N., Dahdouh-Guebas, F., Baeyens, W., and Dehairs, F.: Variability in the origin of carbon substrates for bacterial communities in mangrove sediments, FEMS Microbiol. Ecol., 49, 171-179, 2004.

Brennan, P. J.: Mycobacterium and other actinomycetes, in: Microbial Lipids, edited by: Ratledge, C. and Wilkinson, S. G., London, Academic Press, 203-298, 1988.

Butler, J. L., Williams, M. A., Bottomley P. J., and Myrold D. D.: Microbial community dynamics associated with rhizosphere carbon flow, Appl. Environ. Mircobiol., 69, 6793-6800, 2003.

Carney, K. M., Hungate, B. A., Drake, B. G., and Megonigal, J. P.: Altered soil microbial community at elevated $\mathrm{CO}_{2}$ leads to loss of soil carbon, Proc. Natl. Acad. Sci. USA, 104, 4990-4995, 2007.

Chung, H., Zak, D. R., and Lilleskov, E. A.: Fungal community composition and metabolism under elevated $\mathrm{CO}_{2}$ and $\mathrm{O}_{3}$, Oecologia, 147, 143-154, 2006.

Chung, H., Zak, D. R., Reich, P. B., and Ellsworth, D. S.: Plant species richness, elevated $\mathrm{CO}_{2}$, and atmospheric nitrogen deposition alter soil microbial community composition and function, Global Change Biol., 13, 1-10, 2007.

Cotrufo, M. F. and Gorissen, A.: Elevated $\mathrm{CO}_{2}$ enhances belowground $\mathrm{C}$ allocation in three perennial grass species at different levels of N availability, New Phytol., 137, 421-431, 1997.

Cotrufo, M. F., Ineson, P., and Rowland, A. P.: Decomposition of tree leaf litters grown under elevated CO2: effect of litter quality, Plant Soil, 163, 121-130, 1994.

Curtis, P. S. and Wang, X.: A meta-analysis of elevated $\mathrm{CO}_{2}$ effects on woody plant mass, form and physiology, Oecologia, 113, 299-313, 1998.

DeLucia, E. H., Hamilton, J. G., Naidu, S. L., Thomas, R. B., Andrews, J. A., Finzi, A., Lavine, M., Matamala, R., Mohan, J. E., Hendrey, G. R., and Schlesinger, W. H.: Net primary production of a forest ecosystem with experimental $\mathrm{CO}_{2}$ enrichment, Science, 289, 1177-1179, 1999.

Drijber, R. A., Doran, J. W., Parkhurst, A. M., and Lyon, D. J.: Changes in soil microbial community structure with tillage under long-term wheat-fallow management, Soil Biol. Biochem., 32, 1419-1430, 2000.

Drissner, D., Blum, H., Tscherko, D., and Kandeler, E.: Nine years of enriched $\mathrm{CO}_{2}$ changes the function and structural diversity of soil microorganisms in a grassland, Eur. J. Soil Sci., 58, 260-269, 2007.

Ebersberger, D., Wermbter, N., Niklaus, P. A., and Kandeler, E.: Effects of long term $\mathrm{CO}_{2}$ enrichment on microbial community structure in calcareous grassland, Plant Soil, 264, 313-323, 2004.

Federle, T. W.: Microbial distribution in soil - new techniques, in: Perspectives in Microbial Ecology, edited by: Megusar, F. and Ganthar, M., Slovene Society for Microbiology, Ljubljana, 493498, 1986.

Fierer, N., Schimel, J. P., and Holden, P. A.: Variations in microbial community composition through two soil depth profiles, Soil Biol. Biochem., 35, 167-176, 2003. 
Frankland, J. C., Dighton, J., and Boddy, L.: Methods for studying fungi in soil and forest litter, Meth. Microbiol., 22, 343-404, 1990.

Frey, S. D., Elliott, E. T., Paustian, K., and Peterson, G. A.: Fungal translocation as a mechanism for soil nitrogen inputs to surface residue decomposition in a no-tillage agroecosystem, Soil Biol. Biochem., 32, 689-698, 2000.

Frostegård, Å. and Bååth, E.: The use of phospholipid fatty acid analysis to estimate bacterial and fungal biomass in soil, Biol. Fertil. Soils, 22, 59-65, 1996.

Ghannoum, O., Von Caemmerer, S., Ziska, L. H., and Conroy, J. P.: The growth response of $\mathrm{C} 4$ plants to rising atmospheric $\mathrm{CO}_{2}$ partial pressure: a reassessment, Plant Cell Environ., 23, 931942, 2000.

Gill, R. A., Polley, H. W., Johnson, H. B., Anderson, L. J., Maherali, H., and Jackson, R. B.: Nonlinear grassland responses to past and future atmospheric $\mathrm{CO}_{2}$, Nature, 417, 279-282, 2002.

Griffiths, B. S., Ritz, K., Ebblewhite, N., and Dobson, G.: Soil microbial community structure: effects of substrate loading rates, Soil Biol. Biochem., 30, 369-378, 1999.

Griffiths, R. I., Manefield, M., Bailey, M. J., Whitely, A. S., Ostle, N., McNamara, N., and O'Donnell, A. G.: ${ }^{13} \mathrm{CO}_{2}$ pulse labeling of plants in tandem with stable isotope probing: methodological considerations for examining microbial function in the rhizosphere, J. Microbiol. Meth., 58, 119-129, 2004.

Harwood, D. L. and Russell, N. J.: Lipids in Plants and Microbes, George Allen and Unwin Ltd., London, 1984.

Hu, S., Chapin, F. S., Firestone, M. K., Field, C. B., and Chiariello, N. R.: Nitrogen limitation of microbial decomposition in a grassland under elevated $\mathrm{CO}_{2}$, Nature, 409, 188-191, 2001.

Jäger, H. -J., Schmidt, S. W., Kammann, C., Grünhage, L., Müller, C., and Hanewald, K.: The University of Giessen Free-Air Carbon Dioxide Enrichment Study: Description of the Experimental Site and of a New Enrichment System, J. Appl. Bot., 77, 117127,2003

Jastrow, J. D., Miller, R. M., Matamala, R., Norby, R. J., Boutton, T. W., Rice, C. W., and Owensby, C. E.: Elevated atmospheric carbon dioxide increases soil carbon, Global Change Biol., 11, 2057-2064, 2005.

Johnson, D., Leake, J. R., and Read, D. J.: Transfer to recent photosynthate into mycorrhizal mycelium of an upland grassland: short-term respiratory losses and accumulation of ${ }^{14} \mathrm{C}$, Soil Biol. Biochem., 34, 1521-1524, 2002.

Jongen, M., Jones, M. B., Hebeisen, T., Blum, H., and Hendrey, G.: The effects of elevated $\mathrm{CO}_{2}$ concentrations on the root growth of Lolium perenne and Trifolium repens grown in a FACE system, Global Change Biol., 1, 361-371, 1995.

Kammann, C., Grünhage, L., Grüters, S., Janze, S., and Jäger, H.-J.: Response of aboveground grassland biomass and soil moisture to moderate long-term CO2 enrichment, Basic Appl. Ecol., 6, 351365, 2005.

Kandeler, E., Mosier, A. R., Morgan, J. A., Milchunas, D. G., King, J. Y., Rudolph, S., and Tscherko, D.: Response of soil microbial biomass and enzyme activities to the transient elevation of carbon dioxide in a semi-arid-grassland, Soil Biol. Biochem., 38, 24482460, 2006.

Klironomos, J. N., Rillig, M. C., and Allen, M. F.: Below-ground microbial and microfaunal responses to Artemisia tridentata grown under elevated atmospheric $\mathrm{CO}_{2}$, Funct. Ecol., 10, 527
534, 1996.

Körner, C.: Biosphere responses to $\mathrm{CO}_{2}$ enrichment, Ecol. Appl., 10, 1590-1619, 2000.

Kroppenstedt, R. M.: Fatty acid and Menaquinone analysis of actinomycetes and related organisms, in: Chemical Methods in Bacterial Systematics, edited by: Goodfellow, M. and Minnikin, D. E., Academic Press, London, 173-199, 1985.

Lipson, D. A., Wilson, R. F., and Oechel, W. C.: Effects of elevated atmospheric $\mathrm{CO}_{2}$ on soil microbial biomass, activity and diversity in a chaparral ecosystem, Appl. Environ. Mircobiol., 71, 8573-8580, 2005.

Lu, Y., Rosencrantz, D., Liesack, W., and Conrad, R.: Structure and activity of bacterial community inhabiting rice roots and the rhizosphere, Environ. Microbiol., 8, 1351-1360, 2006.

Lu, Y., Abraham, W-R., and Conrad, R.: Spatial variation of active microbiota in the rice rhizosphere revealed by in situ stable isotope probing of phospholipid fatty acids, Environ. Microbiol., 9, 474-481, 2007.

McMahon, S. K., Williams, M. A. Bottomley, P. J., and Myrold, D. D.: Dynamics of microbial communities during decomposition of carbon-13 labeled ryegrass fractions in soil, Soil Sci. Soc. Am. J., 69, 1238-1247, 2005 .

Montealegre, C. M., van Kessel, C., Russelle, M. P., and Sadowsky, M. J.: Changes in microbial activity and composition in a pasture ecosystem exposed to elevated atmospheric carbon dioxide, Plant Soil, 243, 197-207, 2002.

Moscatelli, M. C., Lagomarsino, A., de Angelis, P., and Grego, S.: Seasonality of soil biological properties in a polar plantation growing under elevated atmospheric $\mathrm{CO}_{2}$, Appl. Soil Ecol., 30, 162-173, 2005.

Niklaus, P. A., Alphei, J., Ebersberger, D., Kampichler, C., Kandeler, E., and Tscherko, D.: Six years of in situ $\mathrm{CO}_{2}$ enrichment evoke changes in soil structure and soil biota of nutrient-poor grassland, Global Change Biol., 9, 585-600, 2003.

Olsson, P. A. and Johnson, N. C.: Tracking carbon from the atmosphere to the rhizosphere, Ecol. Let., 8, 1264-1270, 2005.

Olsson, P. A., Bååth, E., Jakobsen, I., and Söderström, B.: The use of phospholipid and neutral lipid fatty acids to estimate biomass of arbuscular mycorrhizal fungi in soil, Mycol. Res., 99, 623629, 1995.

Phillips, R. L., Zak, D. R., Holmes, W. E., and White, D. C.: Microbial community composition and function beneath temperate trees exposed to elevated atmospheric carbon dioxide and ozone, Oecologia, 131, 236-244, 2002.

Prosser, J. I., Rangel-Castro, J. I., and Killham, K.: Studying plantmicrobe interactions using stable isotope technologies, Curr. Opin. Biotechnol., 17, 98-102, 2006.

Rangel-Castro, J. I., Killham, K., Ostle, N., Nicol, G. W., Anderson, I. C., Scrimgeour, C. M., Ineson, P., Meharg, A., and Prosser, J. I.: Stable isotope probing analysis of the influence of liming on root exudates utilization by soil microorganisms, Environ. Microbiol., 7, 828-838, 2005.

Rillig, M. C., Field, C. B., and Allen, F. A.: Soil biota responses to long-term atmospheric $\mathrm{CO}_{2}$ enrichment in two California annual grasslands, Oecologia, 119, 572-577, 1999.

Rillig, M. C., Wright, S. F., and Eviner, V.T.: The role of arbuscular mycorrhizal fungi and glomalin in soil aggregation: comparing effects of five plant species, Plant Soil, 238, 325-333, 2002.

Rogers, H. H., Runion, G. B., and Krupa, S. V.: Plant responses 
to atmospheric $\mathrm{CO}_{2}$ enrichment with emphasis on roots and the rhizosphere, Environ. Pollut., 83, 155-189, 1994.

Rønn, R., Gavito, M., Larsen, J., Jakobsen, I., Frederiksen, H., and Christensen, S.: Response of free-living soil protozoa and microorganisms to elevated atmospheric $\mathrm{CO}_{2}$ and presence of mycorrhiza, Soil Biol. Biochem., 34, 923-932, 2002.

Sadowsky, M. J. and Schortemeyer, M.: Soil microbial response to increased concentrations of atmospheric $\mathrm{CO}_{2}$, Global Change Biol., 3, 217-224, 1997.

Schäppi, B. and Körner, C.: Growth responses of an alpine grassland to elevated $\mathrm{CO}_{2}$, Oecologia, 1, 43-52, 1996.

Schortemeyer, M., Hartwig, U. A., Hendrey, G. R., and Sadowsky, M. J.: Microbial community changes in the rhizosphere of white clover and perennial ryegrass exposed to free air carbon dioxide enrichment (FACE), Soil Biol. Biochem., 28, 1717-1724, 1996.

Sonnemann, I. and Wolters, V.: The microfood web of grassland soils responds to a moderate increase in atmospheric $\mathrm{CO}_{2}$, Global Change Biol., 11, 1148-1155, 2005.

Stahl, P. D. and Klug, M. J.: Characterization and differentiation of filamentous fungi based on fatty acid composition, Appl. Environ. Microb., 62, 4136-4146, 1996.

Stöcklin, J., Schweizer, K., and Körner, C.: Effects of elevated $\mathrm{CO}_{2}$ and phosphorus addition on productivity and community composition of intact monoliths from calcareous grassland, Oecologia, 116, 50-56, 1998.

Treonis, A. M., Ostle, N. J., Stott, A. W., Primrose, R., Graystone, S. J., and Ineson, P.: Identification of groups of metabolicallyactive rhizosphere microorganisms by stable isotope probing of PLFAs, Soil Biol. Biochem., 36, 533-537, 2004.

Treseder, K. K.: A meta-analysis of mycorrhizal responses to nitrogen, phosphorus, and atmospheric $\mathrm{CO}_{2}$ in field studies, New Phytol., 164, 347-355, 2004.

Treseder, K. K. and Allen, M. F.: Mycorrhizal fungi have a potential role in soil carbon storage under elevated $\mathrm{CO}_{2}$ and nitrogen deposition. New Phytol., 147, 189-200, 2000.

van Groenigen, K. J., Six, J., Hungate, B. A., de Graaff, M. A., van Breemen, N., and van Kessel, C.: Element interactions limit soil carbon storage, Proc. Natl. Acad. Sci. USA, 103, 6571-6574, 2006.
Vestal, J. R. and White, D. C.: Lipid analysis in microbial ecology, BioScience, 39, 535-541, 1989.

Waldrop, M. P. and Firestone, M. K.: Microbial community utilization of recalcitrant and simple carbon compounds: impact of oak-woodland plant communities, Oecologia, 138, 275-284, 2004.

Wardle, D. A., Brown, V. K, Behan-Pelletier, V., St. John, M., Wojtowicz, T., Bardgett, R. D., Brown, G. G., Ineson, P., Lavelle, P., van der Putten, W. H., Anderson, J. M., Brussaard, L., Hunt, W. H., Paul, E. A., and Wall, D. H.: Vulnerability to global change of ecosystem goods and services driven by soil biota, in: Sustaining Biodiversity and Ecosystem Services in Soils and Sediments, edited by: Wall, D. H., Island Press, Washington DC, 101-136, 2004.

White, D. C., Davis, W. M., Nickels, J. S., King, J. D., and Bobbie, R. J.: Determination of the sedimentary microbial biomass by extractable lipid phosphate, Oecologia, 40, 51-62, 1979.

Williams, M. A., Myrold, D. D., and Bottomley, P. J.: Carbon flow from ${ }^{13} \mathrm{C}$-labeled straw and root residues into the phospholipid fatty acid of a soil microbial community under field conditions, Soil Biol. Biochem., 38, 759-768, 2006.

Zak, D. R., Pregitzer, K. S., Curtis, P. S., and Holmes, W. E.: Elevated atmospheric $\mathrm{CO}_{2}$ and feedback between carbon and nitrogen cycles, Plant Soil, 151, 105-117, 1993.

Zak, D. R., Ringelberg, D. B., Pregitzer, K. S., Randlett, D. L., White, D. C., and Curtis, P. S.: Soil microbial communities beneath Populus grandidentata grown under elevated atmospheric $\mathrm{CO}_{2}$, Ecol. Appl., 6, 257-262, 1996.

Zak, D. R., Pregitzer, K. S., Curtis, P. S., and Holmes, W. E.: Atmospheric $\mathrm{CO}_{2}$ and the composition and function of soil microbial communities, Ecol. Appl., 10, 47-59, 2000.

Zelles, L.: Phospholipid fatty acid profiles in selected members of soil microbial communities, Chemosphere, 35, 275-294, 1997. 